\title{
Lexis
}

Journal in English Lexicology

17 | 2021

Humor, creativity and lexical creation

\section{Questioning the purpose and success of occasionalisms as a source of humour in How I Met your Mother}

Adeline Terry

\section{CpenEdition}

Journals

Electronic version

URL: https://journals.openedition.org/lexis/5399

DOI: $10.4000 /$ lexis.5399

ISSN: 1951-6215

Publisher

Université Jean Moulin - Lyon 3

\section{Electronic reference}

Adeline Terry, "Questioning the purpose and success of occasionalisms as a source of humour in How I Met your Mother", Lexis [Online], 17 | 2021, Online since 15 August 2021, connection on 20 August 2021. URL: http://journals.openedition.org/lexis/5399 ; DOI: https://doi.org/10.4000/lexis.5399

This text was automatically generated on 20 August 2021.

\section{(2) $\odot \Theta \Theta$}

Lexis is licensed under a Creative Commons Attribution-NonCommercial-NoDerivatives 4.0 International License. 


\title{
Questioning the purpose and success of occasionalisms as a source of humour in How I Met your Mother
}

\author{
Adeline Terry
}

\section{Introduction}

How I Met Your Mother (HIMYM henceforth) is an American sitcom created by Carter Bays and Craig Thomas, broadcast from 2005 to 2014 on CBS. It has been said to be different from other popular sitcoms (such as Friends) for two main reasons: its complex narrative construction (Cornillon [2006], Mittell [2015]) and its lexical creativity (Sams [2016]). This paper will mostly focus on lexical creativity, and more specifically on the links between lexical creativity and humour in the sitcom. Although the main reason for the creation of a new word is to fill in a lexical or conceptual gap or to fine-tune an existing notion, a new lexical creation can also fulfil different functions at a pragmatic level, for instance for euphemistic or humorous effects, among others. The occurrences under scrutiny in this paper are occasionalisms, that is to say lexemes which are not (yet) part of the lexicon of a given language because they were only used on one or (too) few occasions. The aim of this paper is to study occurrences from the sitcom to show how different functions of occasionalisms and other factors (such as the portrayed relationships or viewer loyalty) ${ }^{1}$ (un)successfully combine to create humour in the sitcom. Humour is not the only aim of such occasionalisms, but an occurrence will be considered as "successful" if/when it reaches the intended effect - in this case, humour. Naturally, the fictitious nature of the sitcom will lead me to distinguish between what happens at the diegetic level and what happens at the interpretative level: (un)successful occasionalisms at the diegetic level may very well be interpreted 
as humorous by the audience (see Dynel [2012b]), which seems to point to a dual purpose of occasionalisms in the sitcom.

The first part of the paper will be theoretical and will focus on nonce formation processes as tools for lexical creativity and humour. It will consist of a discussion of the concepts of "nonce formations" and "occasionalisms" followed by a brief overview of the different nonce formation processes used in HIMYM; this will then allow me to present the different functions that occasionalisms usually assume and to insist on the links between lexical creativity and humour.

3 The second part of the paper will deal with the (un)successfully filled purposes of occasionalisms participating in the humorous process. I will firstly focus on a few salient, creative, humorous occurrences to move on to occasionalisms which are not so successful because they are not understood or whose purpose is rather unconventional: deception. These occasionalisms intentionally confuse or lead the characters and/or the audience astray. I will show that at the diegetic level, those occasionalisms are deceitful tools as they are meant not to be understood by the co-speaker; at the interpretative level, the aim is definitely humorous, which seems to confirm that humour is the main purpose of lexical creativity in How I Met Your Mother.

\section{Nonce formation (processes) and occasionalisms as tools for lexical creativity and humour}

As Poix [2018:2] points out in a study on nonce formation in children's literature, "[c]oining a new word in fiction cannot be compared with spontaneous word formation in speech. Authors purposely using new words or phrases do so for a reason that is highly correlated to the context of their books." The same statement can be applied to sitcoms such as HIMYM, which are also works of fiction, carefully written by scriptwriters. Therefore, this first section presents word-formation processes and focuses on lexical creativity in the light of this particular context.

\subsection{Definition of occasionalisms and nonce formation (processes)}

There has been much discussion on what new words should be called among linguists. Bauer [1983: 45-48], for example, makes a terminological distinction between different types of new complex lexemes at different stages and argues that at the earliest stage, they are called "nonce formations", although he admits that not everyone agrees with this definition:

A nonce formation can be defined as a new complex word coined by a speaker/ writer on the spur of the moment to cover some immediate need. This definition admits new words as nonce formations even when they are totally regular, and even if they go on to become accepted in the language community: not all scholars would necessarily agree with a definition cast in such broad terms. [...] A form ceases to be a nonce formation as soon as the speakers using it are aware of using a term which they have heard already: that is to say, virtually immediately.

Schmid [2016:73] seems to agree with Bauer when he writes that the term "nonceformation [...] emphasizes the idea that a word is only used once in a given situation but never taken up again"; he therefore prefers the term "ad-hoc formation" to refer to the initial use of a word. From a socio-pragmatic perspective, these new words may 
spread in a speech community and become institutionalised; from a structuralist perspective, they may stabilise and become lexicalised (Schmid [2016: 73-77]).

7 Poix [2018: 2] argues that Bauer's definition of nonce formation could not be applied to "nonce formation in literature as it is hard to conceive that an author would coin a word impulsively without much planning and consideration." Although there are probably cases in which this last statement is debatable, most nonce formations in literature are undoubtedly given much thought. Similarly, in HIMYM, as in any sitcom or series, new words are not coined "on the spur of the moment" or "actively formed in performance", in the words of Hohenhaus [2007: 18], as they are carefully planned by scriptwriters beforehand; what is represented as spontaneous conversation in sitcoms is actually oralised text. Poix further quotes Dressler \& Tumfart [2017: 155-156], as they give a definition for the term "occasionalism":

Chanpira (1966) [...] coined the term occasionalism, meaning a new word created for a poetic function at a specific place in a literary text, and which has little chance to be accepted by the language community as a neologism.

Although sitcoms are not literary texts, the term "occasionalism" seems to better apply to these occurrences of new, non-lexicalised words which have little chance of becoming institutionalised and lexicalised and which are not coined on the spur of the moment as they have been elaborated by scriptwriters. The term "occasionalism" is also used by Haspelmath [2002: 39] for new words "that do not really catch on and are restricted to occasional occurrences" or "[w]ords that have been observed at least on one occasion but have not really caught on in the speech community". As Crystal [2000: 219-220] argues:

As soon as people are aware that they have encountered or used a nonce-formation before, therefore, it ceases to be "nonce". "Twice-formations" identify the beginning of the road along which a word has to travel before it is accepted as a neologism.

9 Therefore, as "nonce formation" seems too restrictive, "occasionalism" is the term that will be used in this article to refer to those new lexemes which may be used once or several times in the sitcom but which are neither institutionalised nor lexicalised. "Nonce formation process" will be used to refer to the process (nonce formation processes are defined in 1.3.).

Some occasionalisms in HIMYM tend to be rather creative; lexical creativity is traditionally opposed to productivity, which is defined as "rule-governed innovation" while creativity is "rule-changing" (Lipka [2007:3]), that is to say, "a process of creation that is not, or not completely, rule-governed" (Hohenhaus [2007:16]). Hohenhaus [2007: 18] further argues that occasionalisms and nonce formations can be the result of productive rules or can be creative, meaning that productivity and creativity are linked ${ }^{2}$. The following section focuses on the data set and the methodology used to retrieve the occasionalisms in HIMYM.

\subsection{Data set and methodology}

11 How I Met Your Mother is a sitcom that is composed of 9 seasons and 208 twenty-minute episodes. It follows the main character, Ted Mosby, an architect who is also a hopeless romantic, and his four friends, who all live in Manhattan: Barney Stinson, a bachelor and a womanizer, Marshall Eriksen, a lawyer and Ted's college roommate, Lily Aldrin, a Kindergarten teacher, and Robin Scherbatsky, a Canadian journalist with whom Ted is in 
love through most of the sitcom. The narrative structure is rather innovative as the story is framed by a narrator, older Ted, in 2030; he tells his two children the events that took place from 2005 to 2013, that is to say from the moment he met Robin to the moment he met their mother. The plot largely focuses on the characters' love life, and more specifically on the love triangle between Ted, Robin and Barney, as Marshall and Lily are in a committed relationship (they are said to have met in college and they get married in Season 2).

As Sams [2018: 162-177] points out in a study on word-formation processes in How I Met Your Mother, the sitcom has been praised for both form and content and has a specific linguistic identity ${ }^{3}$ :

The success of the series is, to a large extent, also owing to the fact that it created a recognizable linguistic identity for its characters. In other words, the language used in certain episodes manages to transcend the plot, such that what the characters said often made a greater impression than what they did. [...]

In How I Met your Mother, language use clearly contributes to character development and differentiation, but also distinguishes the series as linguistically innovative. It can be safely assumed that explicit attention was paid throughout the series to crafting the speech of the HIMYM characters to support character development through creative language use, in particular by the use of new words.

Indeed, making up words is central to the interactions of the HIMYM characters. Many of those occasionalisms refer to and thus contribute to reinforcing group-specific antics: this is the case when characters invoke eponymy (to "Mosby" someone is to say "I love you" on a first date because Ted Mosby said "I love you" to Robin on their first date), or when they partake in "slap-bets" and create many occasionalisms that are part of the vocabulary surrounding the bets or simply plays on words in order to scare Barney. There is thus a crucial social aspect to the idiolect of the series on two different levels: on the one hand, it reflects the real-life linguistics of close friend groups ${ }^{4}$ with words becoming "micro-institutionalised", and it also helps to create a relationship between the sitcom and the viewers, who can feel part of this friends' group by recognizing (and perhaps adopting) their linguistic behaviour ${ }^{5}$. As Quaglio [2009: 13] argued:

Viewer identification no doubt plays a major goal on the success of a sitcom. And it is through language that this identification is achieved and popular culture is expressed and reflected.

Beers Fägersten [2016] seems to agree with this statement when she writes that "television both represents and influences our ideas about and usage of language and linguistics resources", and that the language of television can be considered as "one of the many sources of linguistic input and exposure" and as "a mirror of and possibly an influence on the viewer's own usage." Therefore, the humorous occasionalisms in HIMYM can be taken as an example of language in use for the humorous purposes, but also as an example of language that can potentially both reflect and influence viewer language; it also involves the viewer in social bonding, with the characters and/or with other viewers. One of the purposes of the article is therefore to contribute to explaining how the linguistic practices of HIMYM (and more specifically, the use of occasionalisms) reflect communication and creativity, underlining the fact that people use language both to convey meaning and to play.

In order to collect the data, several means were considered. The corpus was compiled with the scripts of the 208 episodes, collected on Subslikescript and on Foreverdreaming 
(cf. bibliography). Subslikescript was favoured because the names of the characters do not appear in the scripts, which allows to have less irrelevant data, but there are a few episodes for which the scripts were not available and were therefore collected on Foreverdreaming. The final file contains around 600,000 words. The number of words is approximative because some stage directions, character names, and song lyrics are sometimes mentioned.

In order to attempt to collect occasionalisms in the scripts, I created a list of stop words by compiling an existing list of 466,553 English words ${ }^{6}$ and a list of 5,493 proper nouns ${ }^{7}$. I then uploaded the scripts in AntConc and extracted the words that were only present in the scripts. The list contained 1,698 words. There were two main problems with this list:

- Firstly, many of the words retrieved thanks to AntConc were not occasionalisms but occurrences due to a missed space (alwaysbeen, backrub), words that were misspelt (answerign, apartement), onomatopoeia (aaaaaaaaaaa, aaarrrggg), etc.

- Secondly, compound occasionalisms did not appear on the list because they are often spelt in two or more words, although they seemed to constitute a large proportion of occasionalisms in the series.

17 As the aim of this paper was not to provide a quantitative study of occasionalisms in the sitcom but rather to analyse a few examples to show how humour works, it seemed pointlessly time-consuming to go through all the occurrences retrieved thanks to AntConc to identify them as occasionalisms and to complete the list by manually retrieving all the occurrences of compounds that could be considered as occasionalisms. Therefore, the occurrences which are analysed in the paper were all retrieved manually by carefully watching the videos with the English subtitles in order to make sure that the spelling was the same as in the official scripts. Not all occurrences were selected, and most of them were taken from the first six seasons as enough data was collected at this point. The occurrences provided in Section 1, which mainly appear in the overview of the different nonce-formation processes, are simply examples which are meant to illustrate each of these processes. The occurrences analysed in Section 2 were retrieved because they were interesting for being not so successful or for being deceptive; they could not have been retrieved and analysed thanks to corpus analysis tools.

In order to confirm that the occurrences mentioned in the paper were indeed occasionalisms, I first checked whether they appeared in the list of 1,698 words that was compiled thanks to AntConc. I then searched the Merriam-Webster online dictionary (which was chosen because it is a reference dictionary of American English) so as to confirm that they were not lexicalised. In order to verify that they were not on the way to become neologisms, occasionalisms were also looked up in the Urban Dictionary, an online collaborative slang dictionary. This, I believe, coupled with the fact that the definition of "occasionalism" provided in 1.1. is rather broad, allowed me to make sure that the occurrences mentioned in this paper were indeed occasionalisms. Finally, an occurrence was labelled as "humorous" when it was followed by canned laughter, even though the humorous potential cannot be entirely attributed to lexical creativity (more on that in 1.5.). 


\subsection{A typology of nonce formation processes}

Word-formation processes have been described by Tournier [2004] and summarised in the table below:

Table 1. Word-formation processes (Tournier [2004: 27])

\begin{tabular}{|c|c|c|c|c|c|}
\hline \multicolumn{6}{|c|}{ LES MATRICES LEXICOGÉNIQUES DE L'ANGLAIS CONTEMPORAIN } \\
\hline \multirow{11}{*}{ 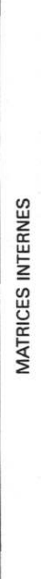 } & \multirow{6}{*}{$\begin{array}{l}\text { NÉOLOGIE } \\
\text { MORPHO- } \\
\text { SÉMANTIQUE }\end{array}$} & \multirow{6}{*}{\multicolumn{2}{|c|}{ IMITATION PHONIQUE }} & 1. PRÉFIXATION & : antinuclear; body $>$ embody $>$ disembody \\
\hline & & & & 2. SUFFIXATION & $:$ kitchenette $;$ grace $>$ graceful $>$ gracefulness \\
\hline & & & & $\begin{array}{l}\text { 3. DÉRIVATION } \\
\text { INVERSE }\end{array}$ & $\begin{array}{l}\text { (to) burgle }<\text { burglar; (to) laze }<\text { lazy } \\
\text { flammable }<\text { inflammable }\end{array}$ \\
\hline & & & & 4. JUXTAPOSTION & $\begin{array}{l}\text { sheep-dog, armchair, statesman, master's degree, point of } \\
\text { view, honeymoon trip, hand-made, give up }\end{array}$ \\
\hline & & & & 5. AMALGAME & $\begin{array}{l}\text { smoke }+ \text { fog }>\text { smog; transfer resistor }>\text { transistor } \\
\text { fantastic }+ \text { fabulous }>\text { fantabulous }\end{array}$ \\
\hline & & & & [6. ONOMATOPÉE & : quack, splash, bang, slush, buzz, zizz \\
\hline & \multirow{3}{*}{$\begin{array}{l}\text { NÉOLOGIE } \\
\text { SÉMANTIQUE }\end{array}$} & CHANGEMEN & T DE FONCTION & 7. CONVERSION & $\begin{array}{l}\text { a) Totale: tunnel, } \mathrm{N}>\text { tunnel, } \mathrm{V} \\
\text { b) Partielle: French, } \mathrm{A}>\text { the French, } \mathrm{N}\end{array}$ \\
\hline & & \multirow{2}{*}{\multicolumn{2}{|c|}{ CHANGEMENT DE SENS }} & 8. MÉTAPHORE & $\begin{array}{l}\text { (she is) a cat, a peach } \\
\text { (he is) a bear, an iceberg }\end{array}$ \\
\hline & & & & 9. MÉTONYMIE & : the press, an iron, the Crown, paperback \\
\hline & \multirow{2}{*}{$\begin{array}{l}\text { NÉOLOGIE } \\
\text { MORPHOLO- } \\
\text { GIQUE }\end{array}$} & \multirow{2}{*}{\multicolumn{2}{|c|}{ RÉDUCTION DE LA FORME }} & 10. TRONCATION & $\begin{array}{l}\text { a) Antérieure: omnibus }>\text { bus, telephone }>\text { phone } \\
\text { b) Postérieure : veterinary surgeon }>\text { vet, public-house }>\text { pub }\end{array}$ \\
\hline & & & & 11. SIGLAISON & $\begin{array}{l}\text { VIP (very important person) } \\
\text { laser (light amplification by stimulated emission of radiation) }\end{array}$ \\
\hline & \multicolumn{3}{|c|}{ EXTERNE } & 12. EMPRUNT & $\begin{array}{l}\text { tutu (fr.), blitz (all.), fiasco (ital.), hacienda (esp.), bungalow } \\
\text { (hindi), coyote (azteque), bonsai (japonais) }\end{array}$ \\
\hline
\end{tabular}

The author distinguishes between internal matrices and one external matrix, borrowing. Within internal matrices, he distinguishes between morpho-semantic wordformation processes, semantic word-formation processes, and morphological wordformation processes. Below, I provide a brief overview of these different wordformation processes, which are used in HIMYM to create occasionalisms and will therefore be referred to as nonce formation processes ${ }^{8}$, along with a few examples.

Semantic word-formation processes correspond to semantic neology, which will not be tackled in this paper as this issue regards lexical creations and lexical neology only ${ }^{9}$, although there are occurrences of conversion (1) or (2), metaphor (3) and metonymy $(4)^{10}$, both PART-FOR-WHOLE and WHOLE-FOR PART, in HIMYM:

(1) MARSHALL: "The Mosby ${ }^{11}$."

LILY: "Noooo, she couldn't Mosby him."

MARSHALL: "She could Mosby the crap out of him."

ROBIN: "What's the Mosby?" (HIMYM 4x24)

(2) TED: “That's not what I'm heying you about!" (HIMYM 2x09)

(3) BARNEY: "You invited me up to your apartment to 'play Battleship.' Is that not an internationally recognized term for sex?" (HIMYM 1x06)

(4) BARNEY: "Dude, you were awesome last night. You were charming, you were funny. You were totally working that girl."

MARSHALL: "You went home with her!"

BARNEY: "Yes, I did." (HIMYM 2X02)

22 As for morpho-semantic word-formation processes, several examples of prefixation and suffixation can be found in HIMYM; un- seems to be a popular prefix in the sitcom 
(5), (6), while $-y$ is a popular suffix which allows the creation of several adjectives such as "coupley" (HIMYM 5x04) or "nicknamey" (HIMYM 5x06):

(5) DRUTHERS: "Can you picture it?"

TED: “I can't unpicture it." (HIMYM 2x06)

(6) SHIP CAPTAIN: "I unpronounce you man and wife." (HIMYM 2x08)

There seem to be few occurrences of occasionalisms created via infixation, because the infix used is always the same and because its status as an infix is debatable. Infixation is a word-formation process that is quite rare in English and that is not mentioned by Tournier [2004] among the main matrices. In the sitcom, "wait for it" is used as an infix in several episodes as one of Barney's linguistic characteristics, mostly in "legen... wait for it... dary!", but not exclusively (for example, "Purg... wait for it... atory" in HIMYM $3 \times 11$ ). On the other hand, backformation is rarer, unless it is combined with other wordformation processes as in (7):

(7) BARNEY: “I'm getting a de-rection.” (HIMYM 6×01)

In this occurrence, Barney removes the supposed prefix $e^{-12}$ and replaces it with the prefix de-, but nothing suggests that he would use rection without the new prefix.

The remaining morpho-semantic word-formation processes are compounding (with juxtaposition and blending) and onomatopoeia. Juxtaposition seems to be frequent in HIMYM, which is not surprising as it is a very productive means of lexical creation in the English language. Naturally, this remark is based on a personal feeling and should be taken very cautiously as it would need to be confirmed by a thorough quantified analysis. It is not easy to define what counts as compounding or juxtaposition from either a semantic or a syntactic viewpoint (Bauer [2018:107]) and to establish a typology of compounds (Bauer [2009:343-355]); the typology proposed in Bauer [2018: 120-125] takes as many as seven criteria into account. As the objective here is not to talk about compounds at length, I will retain the following broad definition: "the formation of a new lexeme by adjoining two or more lexemes" (Bauer [2003: 40]). Compounds in HIMYM can be a combination of two lexemes, as in "our intervention intervention" (HIMYM 4x04), of three lexemes, as in ("the whole Robin-Gael incident" (HIMYM $3 \times 01)$ ). Some compounds ${ }^{13}$ in HIMYM are extraordinarily long (such as "'Thisjust-proves-you-find-the-one-when-you're-not-looking' Isabel” in HIMYM 5x18, an episode in which Lily creates new names for Ted's conquests by juxtaposing one of Ted's quotes about a woman and the first name of the woman). These occurrences will be extensively dealt with in Section 2 as they actively participate in the process of generating humour.

As pointed out by Beliaeva [2019:1], blends are "remarkably diverse in terms of their formal structure" in English. Indeed, they can be created through various types of lexical shortening (see for example Renwick \& Renner [2019]). This is reflected in HIMYM, which displays examples of left-hand-side inner shortening ("Cirque-du-solaid" (Cirque du so[leil] + laid), HIMYM 3×01), of right-hand-side inner shortening ("Lilyal pursuit" (Lily + [Trivial] pursuit), HIMYM 5x18), of double inner shortening ("Marshgamon" (Marsh[all] + [Back]gammon), HIMYM 1x15) and even of more creative occurrences such as multiple right shortenings, as in "Dowisetrepla" (HIMYM 3x07), which stands for a fictitious Manhattan neighbourhood, "Dow[nw]i[nd] [of the] 
Se[wage] Tre[atment] Pla[nt]". This new name is formed the same way "TriBeCa" is and is arguably a parody of "TriBeCa".

Morphological word-formation processes are also present in HIMYM with truncation (see example (8); note that "stache" is rather common and not an occasionalism created in HIMYM) and acronym-formation (9):

(8) ABBY: "Love the 'stache!" (HIMYM 3x13)

(9) BARNEY: "Daughters, lock up your MILSWANCAs."

MARSHALL: "MILSWANCAs?"

TED: "Wait I can get this: Mothers I'd Like To Sleep With And Never Call Again!" (HIMYM 5x08)

Although there are words created by truncation (as in (8)), none of them seem to be occasionalisms, except maybe for "ridonk" (HIMYM 2x05), a clipped version of "ridonkulus". Acronyms are rare as well, probably because the meaning of such occasionalisms is difficult to infer. This is not the case of "G-CWOK" (HIMYM 3x19), whose meaning is never explained and can only be inferred thanks to the context ("Gay Couple Without Kids"), although the term seems to have been coined in the sitcom, according to Internet users on Urban Dictionary ${ }^{14}$.

Onomatopoeias are rare as well and are always combined with another word-formation process, namely conversion (10) or conversion and compounding (11):

(10) BARNEY: "Who would woo? Would you woo?" (HIMYM 4x08)

(11) BARNEY: "[...] an event of the hihon-hihon situation" (HIMYM 4x12)

In occurrence (10), "woo" refers to the sound made by some young women, as explained by Barney earlier in the episode ("A Woo Girl is a type of young woman, who, like the cuckoo bird or the whip-poor-will, gets her name from the signature sound she makes"), while in occurrence (11), "hihon-hihon" refers to the squeaking of the bed. Finally, borrowing, the only external matrix, is not used to create occasionalisms in the sitcom; the only occurrences that were found are words whose use is attested in English and which are therefore not occasionalisms but part of the English lexicon (this is for example the case of "Doppelgänger", which is frequently used to refer to the characters' look-alikes). There are also occurrences of words which seem to be borrowed from a foreign language but whose use is not attested in the source language (such as "Lebenslangerschicksalsschatz" in HIMYM 8x01).

What makes occasionalisms in HIMYM rather creative is that quite often, there is a combination of several word-formation processes: for example, we find a combination of conversion and compounding to create phrasal verbs as in (12), of compounding and blending in (13), and of compounding and sandwich blending in (14):

(12) BARNEY: "Slut up!" (HIMYM 1x20)

(13) TED: "You lost your iloveyouginity." (HIMYM 2x12)

(14) BARNEY: "The former Soviet Republic of Drunk-Of-Her-AssIstan?" (HIMYM 1x11)

Nevertheless, occasionalisms are not only created through word-formation processes or combinations of word-formation processes. Poix [2018: 5-8] argues that in children's literature, "nonce formation" can be achieved by means of word-formation, word deformation, or word creation. Word-deformation processes correspond to the 
deformation of lexical units, mostly "altered to reproduce mistakes made by children in the language acquisition phase" (15), (16), (17) or "muddled up lexemes or phrases meant to produce a humorous effect" $(18)^{15}$ :

(15) MARSHALL: "I am the provider of this apartment and I provided! Provode?

Provided!" (HIMYM 2x18)

(16) TED: "She likes pasgettis." (HIMYM 6x08)

(17) TED: "I'm the mistress. No, not the mistress. The mastress. Master. What

do you call it?" (HIMYM 2x09)

(18) TED: "So the crisis in the Middle East could be solved by..."

BARNEY: "Gaza Strippers. Next."

TED: "Apartheid?"

BARNEY: “Apart thighs." (HIMYM 4x12)

There are however no examples of occasionalisms which are word creations - that is to say, that were entirely created "from scratch" - as they all at least partially follow the rules of one word-formation process of de-formation process. This might be due to the fact that it is probably more difficult for viewers to infer the meaning of word creations than the meaning of occasionalisms that are partly based on already existing words and that tend to be more transparent than opaque (Bauer [1983: 19-20]).

\subsection{Why coin occasionalisms?}

Hohenhaus [2007:17] argues that although the main function of nonce-formation processes is naming, or labelling in order to expand the lexicon, nonce-formation processes can also endorse textual functions, foregrounding or general information condensation effects. This is also the stance taken by Tournier [2004: 195-196], who distinguishes between three main reasons for lexical and semantic creation (and by extension, nonce-formation, as word-formation is one way to create occasionalisms). The first one he mentions is "communication" and corresponds to what Hohenhaus calls "naming". In HIMYM, this function is largely fulfilled by compounding as in HIMYM $4 \times 07$, where Barney coins a name for a new holiday "Not a Father's Day", or HIMYM 4x04, where Ted refers to several of his ornaments such as "the robot cookie jar" or "my elephant lamp".

Hohenhaus [2007:18-21] also mentions cases of textual deixis, which includes compounds which can only be understood in a particular context (19), dummycompounds which include nouns such as "thing" or "business" (20), and episodic compounds ${ }^{16}$, which are established in small-group speech communities:

(19) MARSHALL: "You're gonna have to pay-dia for that." (HIMYM 4x04)

In (19), "pay-dia" is a haplologic blend ${ }^{17}$ composed of "pay" + "[encyclopae]dia"; in this scene, Ted and Marshall argue about the pronunciation of the word "encyclopaedia", Marshall maintaining that it should be pronounced /In,sarklə'pi:diə/ and Ted maintaining it should be pronounced /In,sarklə'peIdiə/, when the shelves on which the encyclopaedia books were collapsed. This blend cannot be understood properly without context, which is the case of most occasionalisms to varying degrees. Textual deixis is also present in HIMYM with dummy-compounds such as "the whole longdistance thing" (HIMYM 3x05) or "this no-fighting thing" (HIMYM 5x06), but also with longer compounds as in (20): 
(20) MARSHALL: "This whole 'leave-it-to-the-universe' thing of yours is insane, Lily." (HIMYM 5x24)

\section{compounds:}

[E]pisodic compounds are not limited to real-world small-group speech communities but also occur in fictional texts where they have the additional function of involving the reader in the story by making him/her "a member" of the small-group community, so that he/she is able to correctly interpret the compound on the basis of preceding episodes in the fictional context.

This statement regarding literary fiction can also be applied to sitcoms: episodic compounds in HIMYM create a representation of a sense of in-groupness among the characters and allow the viewers to feel included in the group as these can be mentioned in several episodes and become part of the inner world of the sitcom; this is for example the case of the adjective "lawyered" 18 , which is used repeatedly by the characters (mostly by Marshall, who is a lawyer, but not exclusively) throughout the nine seasons when they want to show that they have won an argument.

The function of functionalised hypostatisation (first introduced by Lipka [1975: 200])

is defined as follows by Hohenhaus [2007: 22-23]:

$[T]$ he power of words in concept-formation, namely that the mere existence of a name implies to a speaker that a corresponding entity must exist in extralinguistic reality. [...] Normally, hypostatisation is a side-effect of naming. However, it can also be exploited for purposes of textuality. We can speak of functionalised hypostatisation if a WF names something that does not actually exist but is part of the illusion of a fictional context, thus increasing the overall fictional illusion through [...] fictitious words [...]. This has been noted for Science Fiction (SF) in particular [...] but is of course not restricted to this genre [...].

Functionalised hypostatisation is therefore the process of naming something which does not exist but is part of the fictional context - in this case, of the plot and setting of the sitcom; this function appears in the sitcom when Barney gives fake history lessons (on "Desperation Day", the day before Valentine's Day, created by "St Desperatus" in HIMYM 6x16). It makes the creation of a sort of mythology possible within the sitcom, or rather in Barney's mind as the other characters do not fall for it. Hohenhaus [2007: 22] notes that in parody, "their semantic 'pointlessness' and lack of motivation is more conspicuous"; its aim is no longer to increase fictional illusion but rather to create humour.

Hohenhaus [2007:23-24] also mentions the function of attention-seeking or foregrounding, which is closer to the creativity end of the productivity/creativity scale. He adds that it is "often linked with the overarching function of humour". This overarching function is also mentioned by Tournier [2004: 195-196], who brings out three main motivations behind word-formation, namely communication (or naming), the principle of least effort (with clipping, for example) and playful impulses ${ }^{19}$, which he defines as follows (Tournier [2004: 195-196]) 20:

And so there are words - which can be considered useless - that are created for fun [...]. Human language is also a playground where people feel the need to play as on other playgrounds: the third motivation behind lexical creation is the playful impulse. [...] [T]hese motivations can be combined, two or three of them at a time, to create a lexical unit. 
cording to Tournier [2004:197], all word-formation processes can respond to a playful impulse and they can also combine; however, he does not specify whether some word-formation processes tend to be privileged for humorous lexical creativity ${ }^{21}$.

\subsection{Occasionalisms as a source of humour for the audience in sitcoms}

Before focusing on the links between lexical creativity and humour, it is noteworthy to specify which approach to humour will be privileged in this paper. According to Dynel [2013], humour theories are generally divided into three general approaches: superiority, incongruity, and relief.

In superiority theory, the audience laughs at someone that is represented as (being) inferior to them or at the misfortunes of someone. As Ross [1998: 53] points out, this is a case of humour with a target. Although this approach may be relevant, especially when it comes to situational humour, it is obviously not the most appropriate when it comes to linguistic humour. Relief theory, on the other hand, implies that humour allows the audience to release a form of tension or to overcome their inhibitions, and hence has a sort of cathartic effect. According to Ross [1998: 63], "[t]he psychic release theory of humour explains the triggering of laughter by the sense of release from a threat being overcome - such as a reduction of fears about death and sex." This approach to humour cannot be applied to all cases of humorous occasionalisms either, although the humorous dimension of some of them may partly be explained by this approach. I will therefore mainly rely on the incongruity approach, following Dynel [2013: 1], who argues that it is the most compatible with other linguistic approaches:

While all of them are addressed by linguists, it is the incongruity approach that prevails in linguistic scholarship. This is, most likely, because it accounts for the cognitive and pragmatic processes underpinning the understanding of humorous texts and because it is compatible with other linguistic notions and approaches to discourse comprehension originally put forward outside humour studies.

Ross [1998: 7] defines it in the following words: "the incongruity theory focuses on the element of surprise. It states that humour is created out of a conflict between what is expected and what actually occurs in the joke." In the case of occasionalisms, humour arises from the incongruity between what is expected - the words we know, the words that exist in the lexicon - and what actually occurs - a completely made-up word, a playful occasionalism.

43 Humour also relies on a form of complicity between the humourist and the audience, or as Nash [1985:4] puts it, it "nearly always supposes some piece of factual knowledge shared by humorist and audience." In the case of occasionalisms, although the audience do not recognise the words per se, they may more or less consciously recognise the word-formation processes, infer the meaning of the newly coined occasionalism and understand the humorous intent behind it. Whether an occasionalism is humorous or not depends on whether the viewers can easily infer the meaning of the new word. The issue of word-meaning inference is not specific to humorous occasionalisms as it necessarily occurs every time a speaker encounters a new word. Nevertheless, in a sitcom, as I will explain in more detail in the second section of this paper, humour can arise because the meaning of the occasionalism cannot be inferred (absurd humour) or can only partially be inferred. The viewer might accept that the occasionalism is 
unintelligible and still laugh. However, as Bell [2015:3] points out, humour can also be unsuccessful if the viewers cannot infer the meaning of an occasionalism:

Humorous communication can fail for many of the same reasons that serious communication fails. Misunderstandings occur when one participant uses words that another is not familiar with, when a hearer lacks the background information to make appropriate inferences, or simply when a factor such as noise interferes.

A related question is: "are some nonce formation processes favoured for humour?" Sablayrolles [2018] has identified word-formation processes for "playful neologisms". Although the examples he provides are all taken from French, the general conclusions he draws can partly be applied to English humorous occasionalisms as well, on the basis that word-formation processes are similar in English and French (though not in the same proportions) and that the most humorous occasionalisms tend to be those in which there is a form of salience and incongruity between what is expected and what actually occurs. According to him, a large part of playful occasionalisms come from "extragrammatical morphology" [2018: 191], that is to say, blends [2018: 191], "paronymic deformations" [2018: 194], de-formation of expressions [2018: 198] and inflexional neology [2018: 198]. Renner [2015:119] also acknowledges that blends are particularly creative and playful (just like backronymy ${ }^{22}$ ), in comparison to compounding, which is playful but not necessarily creative, while clipping is creative but not playful; this is also the argument given by Nash [1998: 142-143], which seems to point towards the conclusion that blends could be the most humorous word-formation and nonce formation processes. Renner [2015:130-131] argues that formal complexity, structural transgression, graphic play on words, semantic play on words and functional ludicity are all features that can increase the playfulness of blends. Blending is indeed quite often resorted to in HIMYM, such as in "Tedological clock" (HIMYM 1x21), a blend of "Ted" and "biological clock", or in the examples mentioned in 1.3. As pointed out by Sablayrolles [2018: 192], they are salient because they constitute some incongruity with what is ordinary, in this case, "biological clock."

Occurrences of the other word-formation processes related to the field of "extragrammatical morphology" mentioned by Sablayrolles [2018] are also to be found in HIMYM; paronymic deformation corresponds to what was called "word-deformation" in 1.2., and therefore to examples (15) to (18). These tend to be humorous because they provoke a discrepancy between the linguistic knowledge expected of speakers and a grammatical or lexical mistake (Sablayrolles [2018: 196]). In that respect, paronymic deformation can be interpreted both thanks to incongruity theory and superiority theory, which might explain why it can produce humorous occasionalisms. There are also occurrences of deformation of expressions as in HIMYM 1x15, when Barney says: "Here's the mini-cherry on top of the regular cherry on top of the sundae of awesomeness that is my life." Finally, there are a few examples that resemble inflexional neology but that are in fact probably inflexional irregularities as those forms may not be entirely new although they deviate from the norm. This is the case of "legendarier", which James uses in HIMYM 2x10: the expected form is "more legendary", but uses of "legendarier" had probably been attested before HIMYM. The humorous dimension of these last two examples also largely relies on incongruity, although inflexional neology also draws on superiority.

Finally, Sablayrolles [2018: 200-205] also mentions all the cases in which there is a form of discrepancy in constructional morphology, for example in compounding, derivation, re-motivation. He explains that these tend to be humorous when there is an 
unexpected - or incongruous - association from a semantic point of view (Sablayrolles [2018: 201]).

Nevertheless, it should be kept in mind that the humorous potential of an occasionalism can only be fulfilled if all other conditions are met. As Nash [1985:12] argues: "Paradoxically, linguistics in the strictest sense may not comprehend the humorous activity of language. Humour is an occurrence in a social play." Other factors have to be considered, such as the context and co-text of utterance, to start with, but also paralinguistic features such as gestures and facial expressions, or prosody, to name a few. Given the present format, these will not be dealt with extensively in this article but may constitute an interesting lead for further research. It also depends on the recipient and the interpretation they make of the occasionalism, especially as humour in a sitcom involves a third-party. This explains why it seems impossible to rank nonce formation processes from the most productive to the least productive (and therefore that is not what I will attempt to do). This is what Munat [2015: 101] argues:

[L]udicity is a property of all new word formations. It is an important metacommunicative strategy and the degree of ludicity is directly dependent on the communicative goal and context, not on the type of word formation or on the playful modification of the rules.

In HIMYM, not all occasionalisms - not even blends - are necessarily interpreted as humorous. This is particularly true of the occurrences of lexical creativity on the topic of sex. Consider the following examples:

(21) Barney: "We are on the cusp of moving from out-of-towners to in-theirpantsers. Ay-o." (HIMYM 3x02)

(22) TED (NARRATIVE VOICE): "Kids, October of 2012 kicked off the autumn of breakups. And Barney, having broken his engagement with Quinn... was slowly trying to pick himself back up."

BARNEY: "Welcome to Bangtoberfest! Have a Bangtoberfest T-shirt. I'm back! Have a Bangtoberfest T-shirt. I'm single again. Sorry about your eye. I'm available."

TED (reading the inscription on the T-shirt): "Bangtoberfest. This time it's really not personal."

ROBIN: "Barney, you just went through some really big emotional stuff. You need to give yourself some time to heal." (HIMYM 8x03)

In the scene in (21), in which Barney is talking to Ted, Ted is represented as laughing while in the scene in (22), no one at the bar is pictured as smiling or laughing. It could be concluded that the humorous potential of blends is not always fulfilled as "in-theirpantsers" (21), an occasionalism coined via compounding and derivation, triggers a response in Ted while "Bangtoberfest" (22), a blend, does not. Nevertheless, other factors must also be taken into account. In (21), the co-text seems to have an influence as "in-their-pantsers" is opposed to "out-of-towners" and the two words rhyme (they both end in /ərz/). The context also probably plays a role in the interpretation of these occasionalisms: (21) occurs early in the sitcom (Season 3), when Barney and Ted are both single. On the other hand, (22) occurs much later, when Ted becomes desperate to meet "the one" and is no longer interested in dating and one-night stands. Moreover, at this point in the sitcom, Robin and Barney dated and split up and Barney's statement could therefore be considered as offensive to her; an unspoken taboo has been broached and a limit has been crossed. However, even if the reaction of the characters in these two scenes differs, in both, canned laughter can be heard in the background. 
This leads me to an important distinction that should be made between what is humorous for the characters (at the diegetic level) and what is for the audience. The participants in a sitcom interaction are represented in the graph below:

Figure 1. Participants in a film/series/sitcom interaction (Dynel [2012b: 172])

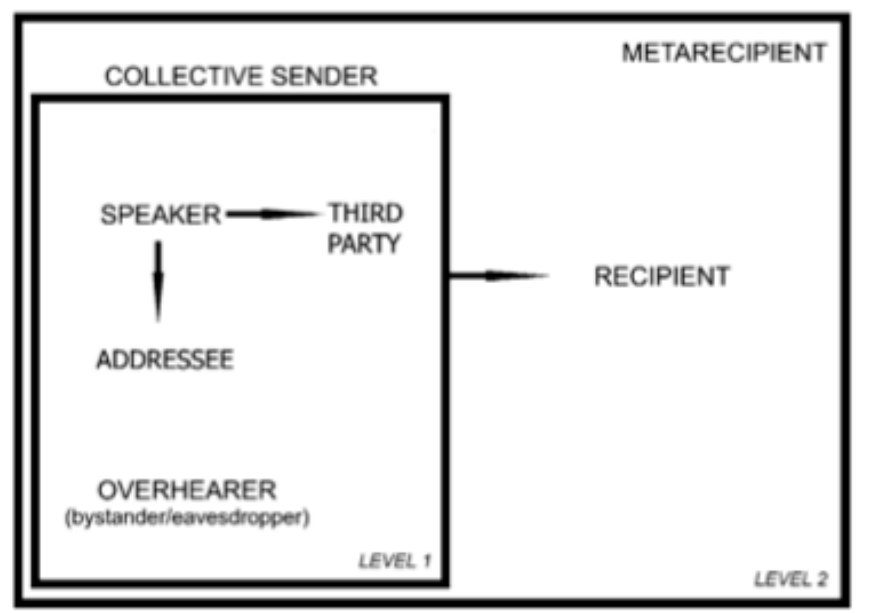

Figure 2. Participants in a film interaction (in one turn) on two levels of communication.

Dynel [2012b] distinguishes between "level 1", that is to say, the diegetic level, in which the characters interact (speakers, addressees, third parties, and overhearers), and "level 2", which regards the interactions between the collective sender (the directors, scriptwriters, etc.) and the recipient (the audience). At "level 3", the metarecipient (scholar, linguist, critic, etc.) analyses the whole. ${ }^{23}$ What is humorous at one level is not necessarily humorous at another. So how do we decide which occasionalisms are humorous and which are not? Although level 1 and the representation of the interactions between the characters should be taken into account, it seems to me that the best criterion to decide whether to label an occurrence as humorous from the perspective of the viewer or not is the presence (or absence) of canned laughter ${ }^{24}$. Ross [1998: 1] writes:

There is a strong social aspect to the way people respond to humour. If you watch your favourite comedy in the presence of people who remain straight-faced, it can stop you from finding it funny. Because it's important to sense other people are responding to humour, 'canned laughter' is used for television or radio comedy.

In other words, in sitcoms, canned laughter indicates what is supposed to be funny in the minds of the creators of a given sitcom, and laughter is a conventional and socially expected response. It should indeed be kept in mind that the real recipient is the audience. Even though it is difficult to measure the reaction of the audience, it is possible to label an occurrence as potentially humorous as opposed to funny, for humorousness is theoretical while funniness is situational, as pointed out by Dynel [2012a: 74]:

Humorousness is a binary category representing a stimulus's theoretical capacity to induce a humorous response in the hearer, while funniness is a gradable category describing the degrees of appreciation of humour as perceived by individuals. [...] Also, whether the underlying incongruity is conducive to a humorous response depends on several factors. 
51 Moreover, as canned laughter is overwhelmingly present in the sitcom, there are very few situations in which an occasionalism is not followed by canned laughter; only one occurrence was found, which is parenthetically rather surprising as the entire line in which the compound appears displays language creativity ${ }^{25}$. Of course, it is difficult to explain what proportion of humorousness is due to the presence of an occasionalism or to other factors (or the combination of the two), which is why micro-analyses are required.

The aim of Section 2 is twofold, although the general aim is to focus on the purpose and success of occasionalisms in HIMYM. It first focuses on the analysis of a few selected occurrences which are salient, playful, humorous and creative and attempts to explain how and why they are definitely part of HIMYM's approach to humour. The study will not be quantitative as it seems arduous, time-consuming, and ultimately unreliable to try and determine which nonce-formation processes are more productive to create a humorous effect without taking the full context and co-text into consideration. Microanalyses will be privileged as they are far more relevant in such a context. This will allow me to move on to the analysis of a few occurrences in which the purposes of occasionalisms seem less conventional but also participate in the generation of humorous effects.

\section{2. (Un)successfully fulfilled purposes of occasionalisms as a tool for humour in HIMYM}

53 By "the purpose of occasionalisms" I understand the function(s) that speakers or collective senders intend to give to these occasionalisms. This is not necessarily the same at level 1 and level 2. Occasionalisms have various functions at the diegetic level (see the functions and the examples provided in 1.3), and I have argued that these functions can naturally combine and often do, in the sitcom. However, these functions can be different at level 2: in the occurrences presented in this part, all the occasionalisms aim to fulfil a humorous function at level 2; the canned laughter is taken to indicate that it is their main purpose.

In addition, an occasionalism can be deemed "successful" if it "successfully" passes the stages of lexicalisation and institutionalisation. This is not the definition of "successful" that is adopted in this study as occasionalisms, by definition, are newly created words which have little chance of becoming accepted as part of the lexicon. In this study, an occasionalism is deemed "successful" when its intended purpose(s) is/are accomplished. One of the basic underlying purposes of occasionalisms, one that I have not mentioned so far, is to be understood both by the characters and by the audience. This cognitive process is described by Schmid [2008: 10]:

When confronted with a previously unknown complex lexeme, hearers have no choice but to rely on analytic interpretations, since a search for an entry of the whole word in their mental lexicon yields no result. Essentially, analytic understanding is based on three types of information: the meanings of the constituents, hearer's knowledge of the instantiated word-formation pattern and its known 'meanings', as well as any relevant information retrievable in the context. Hearers will activate and bring together the forms and meanings of the known constituents to form a contextually plausible and appropriate interpretation by means of a non-routinized, non-automatic process. 
All other purposes and functions quite logically derive from this very basic assumption that occasionalisms will be understood and that they can combine to serve a greater purpose: humour. As Bell [2015:11] argues, "humor often implies an attempt to use language creatively", and I have shown that occasionalisms are an instance of linguistic creativity. Nevertheless, Bell [2015:11-12] also argues that occasionalisms can contribute to failed humour as well:

[L]inguistic creativity is inherently risky, as the speaker must construct an utterance with meaning that in unconventional, yet not so unusual as to be irretrievable by the hearer. This interplay is important for the study of failed humor, as it suggests that we might expect for failure to occur either when an attempt at humor is overly formulaic or is too creative and unusual for a given audience.

How can the (un)successfully fulfilled purposes of occasionalisms participate in the creation of humour in the sitcom?

\subsection{Salient, successful, humorous occasionalisms in HIMYM?}

In addition to the occasionalisms that were mentioned in Section 1, there are salient, creative, sometimes repeated uses that seem to successfully fulfil humorous purposes and that actively take part in HIMYM's approach to humour. Many of these occasionalisms follow the rules of creativity rather than those of productivity, meaning that they question and bend the rules of word-formation processes. They thereby seem to successfully fulfil the function of foregrounding, which is closely linked to the humorous function. One striking example is the presence of extraordinarily long compounds. Some of them are dummy-compounds (Hohenhaus [2007: 18-21]) which are particularly salient because $\mathrm{N}_{2}$ is an entire sentence converted into a noun, as in examples (23) and (24):

(23) TED: “This isn't one of those 'I-came-all-the-way-over-here-because-Iwant-you-back' things.” (HIMYM $3 \times 01$ )

(24) TED: "The whole Jenkins-peed-out-the-window-of-a-cab story." (HIMYM 5x13)

This is potentially humorous as there is a form of incongruity in the length of $\mathrm{N}_{2}$ as well as the speed of Ted's speech delivery, but there is no incongruity in the association of $\mathrm{N}_{2}$ and $\mathrm{N}_{1}$ as $\mathrm{N}_{1} \mathrm{~s}$ "thing" or "story" can be associated with virtually any noun; moreover, the main function of these two compounds remains naming something related to the context, although humour can derive from them, and both the characters and the audience can easily infer the meaning of these dummy-compounds, which means that they successfully fulfil their functions of naming and of textual deixis. Other extraordinarily long compounds seem to have a higher humorous potential as there is a new incongruous association, as in occurrences (25) and (26), although the incongruity of the associations cannot fully account for the humorous potential and other elements participate:

(25) MARSHALL: "You know what? Excuse me if I don't want to get married barefoot in the woods next to Lake No-One's-Going-To-Drive-That-

Far." (HIMYM 1X12)

(26) BARNEY: "This is not the 'Natural-Stuff-That-Happened-No-More-

Than-Five-Minutes-Ago Museum'.” (HIMYM 6x08) 
In (25), Marshall and Lily are in the middle of an argument about the organization of their wedding and the occasionalism, "Lake No-One's-Going-To-Drive-That-Far", is salient and creative on several levels: firstly, once again, it successfully fulfils its foregrounding / attention-seeking function as it is a case of compounding with an entire sentence being converted into a noun; this is what Tournier [2004: 111-112] would call partial vertical conversion. This is reinforced by the fact that the noun is placed at the end of the sentence, thereby finishing Marshall's statement in a blaze of glory. Secondly, a proper noun with no extra-linguistic referent is coined, and both Lily and the audience are aware of that. The new proper noun is diverted from the primary referential function of proper names to endorse other functions, essentially a description of the lake and humour. Its purposes on level 1 (being cynical towards Lily and humour) and level 2 (primarily humour) are successfully achieved. In (26), the humorous potential of the compound partly comes from the implied opposition between "history" and "stuff that happened no more than five minutes ago", which can easily be inferred (all the more so as the episode takes place in the Museum of Natural History), as well as the blatant violation of the principle of least effort, which creates incongruity.

With extraordinarily long compounds combined with conversion, humour can also stem from an opposition between two compounds, as in HIMYM 3x02 with "'Thank-Godwe're-alive' sex. It's even better than "II-can't-believe-you-just-proposed-to-me' sex" 26 . The opposition also concerns other occasionalisms created via a combination of nonce formation processes; consider the following example, which could fall within the category of deformation of expression (27):

(27) BARNEY: "This slot is Vice-President of Awesome, and you're like, Assistant Undersecretary of Only Okay." (HIMYM 3x18)

The titles "Vice-President of XXX" and "Undersecretary of XXX", usually given to members of the government, are distorted and combined with conversion to create new titles in the fictional world of Barney Stinson; it successfully fulfils the function of hypostatisation as the co-speaker, Randy, blindly believes his hero, Barney. Humour comes from the incongruous association of official titles and "Awesome" and "Okay"; nevertheless, as this statement is also purposely offensive to Randy, the humorous dimension can also partly be explained thanks to superiority theory. Finally, the humorous potential might also come from the fact that Randy is not represented as laughing while canned laughter can be heard in the background; this encourages the audience to perceive the occasionalisms and the situation as incongruous.

The occurrences presented at the beginning of this section can be called rather successful as they fulfil their intended purposes. There are nevertheless cases when their success seems mitigated: functionalised hypostatisation, for instance, is frequently presented as not quite successful. Barney resorts to this function of occasionalisms to invent a new identity for himself and trick women into going home with him quite frequently. In HIMYM 5x08, for example, he pretends he works for the SNASA (which stands for "Secret NASA") and has been to "the smoon". The woman he is trying to seduce believes him, which makes the occasionalism successful. However, when Barney relates the story to his friends, he is not so successful for two different reasons. On a very basic level, they immediately perceive that he is lying and do not accept the existence of these concepts; additionally, when relating this story to his friends, Barney expects some kind of humorous response on their behalf, but they do 
not laugh at his use of occasionalisms, probably partly because they consider that the occasionalism is ill-formed or ill-defined and mainly because they consider that Barney has overstepped the limits once again and that his attitude is repulsive: Lily calls Barney a "smoron". For the audience, the existence of the "SNASA" and the "smoon" seems so incongruous that functionalised hypostatisation is not successful, which gives rise to humorous potential, all the more so as they can also mock the gullibility of the young woman (humour draws both on incongruity and superiority), side with Lily and respond to her creative coining. Finally, these occasionalisms could also be argued to be successful in that they partake in the characterisation of Barney and in the interactions between the characters.

The purposes of occasionalisms are also successfully fulfilled in the various running jokes relying on nonce formation processes that are to be found throughout the sitcom. One example of these are the repetitive deformations of the noun "high-five", muddled up to produce a humorous effect, mostly by Barney: these occasionalisms are created through blending via right-hand-side inner shortening ("Phone five" HIMYM 1x03,

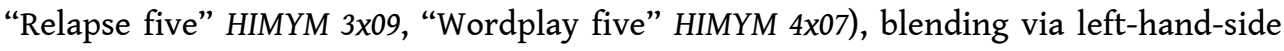
inner shortening ("High-twos" HIMYM 1x15, "High six" HIMYM 6x01), compounding ("Freeze frame high five!" HIMYM 1x14), or simply the addition of an adjective ("Hypothetical high five" HIMYM 2x02). One occurrence combines blending via righthand-side inner shortening and the addition of an adjective ("Solemn low five" HIMYM $2 \times 14$ ). These occasionalisms successfully fulfil their function of foregrounding and of humour, firstly because the audience notices they are incongruous, and also because they are disseminated throughout the sitcom: this leads to the creation of a community and of in-jokes. Humour rises from the variety of nonce formation processes, from creativity and from repetition rather than from one particular nonce formation process. These occasionalisms are generally depicted as being successful as they are interpreted as such by the other characters, with a few exceptions.

61 Another example of successful humorous running joke relying on occasionalisms and creativity is the "slap bet". The "slap bet" (itself a creative compound) is first mentioned in HIMYM 2x09; it refers to a bet in which the winner gets to slap the loser in the face and leads to the creation of numerous occasionalisms:

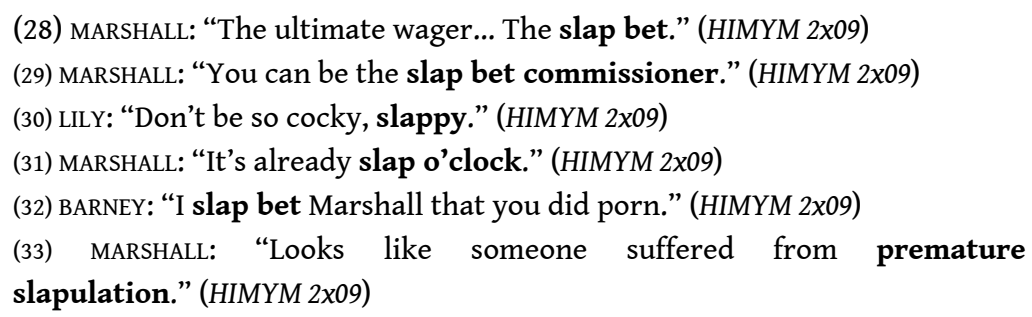

In these scenes, the characters are all depicted as being extremely serious, which makes the functions of these occasionalisms at level 1 quite difficult to identify. At level 2, however, the seriousness displayed by the characters is at odds with the creativity and playfulness of the terms they use: the ultimate goal is undoubtedly humour, as testified by the canned laughter. Some of these occasionalisms tend to become micro-institutionalised in the sitcom as they are re-used in other episodes and become accepted in the language community constituted by the characters. Both characters and loyal viewers are rewarded by these running jokes: recognition boosts the appreciation of humour. Not only can the characters and the viewers execute on- 
the-spot analysis and resolve the incongruity, but the latter can also recognise the variation on the theme - a continued incongruity - and are therefore rewarded for being loyal viewers ${ }^{27}$. This is the case when "slap bet" (28) and "slap bet commissioner" (29) are re-used in HIMYM 3x09 and HIMYM 5x09 and when new occasionalisms are also coined:

(34) MARSHALL: "This is going to be the best Slapsgiving ever." BARNEY: "What?"

MARSHALL: "I said this is going to be the best Thanksgiving ever." (HIMYM $3 \times 09)$

(35) MARSHALL: "Oh hey, by the way, if anyone wants to come over early Thursday, we can watch the Slapsgiving Day Parade."

BARNEY: "Well, there, you said it again!"

MARSHALL: "Said what?"

BARNEY: "Slapsgiving."

MARSHALL: “Oh, I guess I did. You know why? I've invented a new holiday: Slapsgiving It's the one day we set aside each year to gather together and give slaps." (HIMYM 3X09)

(36) MARSHALL: "Oh, no! The slap-petizers." [...]

BARNEY: “I'm not scared.” [...]

MARSHALL: "Then why is your right cheek twitching?"

BARNEY: "It's not."

MARSHALL: "Maybe it's because Future Me slaps Future You so hard it reverberates back to the present, shattering the time-slap continuum." [...]

BARNEY: "Please don't slap me. [...] Oh, God! Don't slap me again! I don't want to get slapped again, and the first two times hurt so bad, I don't like it! I don't like it one bit! [...] I can eat, I can't sleep, I've lost ten pounds, my suits are wearing me. You know what? I'm out of here." (HIMYM 3x09)

(37) BARNEY: "Marshall, you're not eating! Did something spoil your slappetite?" (HIMYM 3x09)

At the level of the characters, the main purpose of these occasionalisms (34), (35), (36) is rather unusual: they aim at repeating the word "slap" to remind Barney that he is going to get slapped at some point and to make him scared, which he argues is not successful until he finally flinches (36). It also aims at humour and the creation of a feeling of in-groupness with the other characters. Once again, linguistic incongruity combines with a form of mockery to create humour. At the level of the audience, the combination of the creativity of the occasionalisms and the creativity given to their function leads to the overarching function of humour and contributes to making the audience feel included through the exclusion of Barney. Now consider the occasionalisms coined in HIMYM 5x09:

(38) MARSHALL: "Slapsgiving two: return of the slap!" [...]

MARSHALL: "Life is short. I figured, Slap-e Diem. Rule number one: the slap must occur before sundown, so as not to interfere with Lily's meal. Two, you have to decide who gets to do it ${ }^{28}$. Three... We're going to tie Barney to this chair, which shall henceforth be referred to as the slapping throne."

(39) TED: "No seriously Robin, you should get the slap. You're a great slapper. In fact, I want to study under your tutelage. I want to be your slapprentice."

ROBIN: "Don't sell yourself short there. You're a slapping Rockstar. Your name should be Eric Slapton."

(40) TED: "This slap was supposed to be a wonderful thing, a gift, and... it's turned us against each other." 
ROBIN: "My God, you're right. This once pure fruit has turned into a poison

slapple. You know what? Seriously, you take it."

TED: "Are you sure?"

ROBIN: "Slap-solutely."

Marshall's strategy (38) resembles the strategy he adopted in HIMYM 3x09: "Slapsgiving", for example, is re-used, while new occasionalisms such as "Slap-e diem" and "slapping throne" are coined, aiming both at scaring Barney and making the other characters laugh. What is different in this episode is that not only are the occasionalisms adopted by the language community, but other characters also create new occasionalisms based on the word "slap" ((39), (40)), while previously, only Marshall played with creative uses of "slap" in occasionalisms. The characters tend to resort to various nonce formation processes, but mostly to blending, which is not surprising as it is one of the word-formation processes that retains the highest humorous potential: right-hand-side inner shortening ("Slapsgiving" (Slap + [Thank] sgiving, as Slapsgiving replaces Thanksgiving) in (34), (35), (38), or "Slape-diem" (38)), haplologic blending ("slap-petizers" (36), "slappetite" (37), "slap-prentice" (39), "slapsolutely" $\left.(40)^{29}\right)$, or sandwich blending ("time-slap continuum" (36) ${ }^{30}$, "Eric Slapton" (39)). Other creative occasionalisms such as "slapulation" (33) seem a bit more difficult to analyse although it seems to be formed thanks to several suffixes; humour partly rises from the fact that the principle of least effort is not respected as the action of giving a slap could simply be referred to as "slapping", which makes "slapulation" seem incongruously long. In these examples, creativity and humour come from repetition as most occasionalisms start with "slap". This successfully participates in the characterization within the sitcom.

In the line of "slapulation", other occasionalisms partly retain a humorous potential because they go against the principle of least effort and bend the rules of productivity to lean towards creativity, for example by playing with morphemes. This is the case in occurrences (41) and (42):

(41) MARSHALL: “This isn't March madness, this is March meticulouslythoughtoutness." (HIMYM 3x14)

(42) BARNEY: “Robin's more than just awe 'some'. She's awe 'quite a bit'. She's awe 'a whole darn lot'." (HIMYM $3 \times 14$ )

In (41), the adjective "mad" in "madness" is replaced with an adverb and a past participle, "meticulously thought out", which functions as an adjectival phrase, while in (42), the suffix -some is understood as the quantifier some and replaced with "quite a bit" and "a whole darn lot". Interestingly, in both (41) and (42), the occasionalisms successfully fulfil a hyperbolic purpose, which arguably forms part of the overarching function of humour both at level 1 and level 2. In (42), this is reinforced by the lengthening of the vowel in "awe" at the beginning of each occasionalism.

The occasionalisms mentioned above all fulfil different functions and need to be analysed in the light of a variety of elements, but they nevertheless all have one common basic purpose: to be understood by both the characters and the audience. In that respect, they can all be considered as successful. However, some occasionalisms in the sitcom are purposely not so clear in meaning and require some further explanation, which might make them unsuccessful on that level. Consider example (43): 
(43) TED: "Hey, is that a toilet in your kitchen?"

ROBIN: "Or a stove in your bathroom?"

LILY: "Oh, that's not just a stove. That's a stovenkerator: a combination of a

stove, oven, sink and refrigerator. Stovenkerator. Isn't that futuristic?"

TED: "God, I hope not." (HIMYM 2x05)

When Lily first utters "stovenkerator", the camera focuses on Ted and Robin, whose facial expressions show they do not fully grasp the concept of "stovenkerator", even if the context helps convey the general idea. My hypothesis is that the occasionalism derives from too complex a blend, relying on four words brought together through haplologic blending and right-hand-side inner shortening, making the final result quite opaque. Interestingly, at level 1, the main purpose of the occasionalism seems to be a variation of functionalised hypostatisation which aims at creating a new fancy word to make an object - and consequently, reality - sound "fancier" than it is. This purpose in not successfully achieved because of the discrepancy between the very small, insalubrious apartment Lily has just moved into and her enthusiasm, together with the opacity of the meaning of the occasionalism she coins. Nevertheless, at level 2, the occasionalism successfully participates in the humorous strategy. The opacity of the meaning of the occasionalism does not prevent the humorous function from being fulfilled, quite the contrary. Something similar unfolds in HIMYM $4 \times 18$, when the American characters discover the existence of Canadian sex acts:

(44) LILY: "What the hell is a 'Two-Hand Zamboni'?"

ROBIN: "Let's just say, the only thing the woman is wearing is skates on her hands."

LILY: “A 'Manitoba Milk Bag'?"

ROBIN: "Okay, it's like a 'Chicago Mustache', but the person on the bottom is wearing a snowsuit."

LILY: "A 'Newfoundland Lobster Trap'?"

ROBIN: "Don't know. Don't want to know. Those Newfies are out of control."

(HIMYM 4x18)

The names of the Canadian sex acts all rely on compounding and on extremely incongruous associations. As the meaning of the compounds is not compositional, they seem rather arbitrary, except for the fact that they all contain some reference to Canada, and the characters as well as the audience are unable to infer their meaning. The "explanations" given by Robin do not help understand their meanings. The fact that they should not fulfil the basic purpose of being understood is actually what conveys humour at level $2^{31}$, once again in combination with other factors such as the mimics Lily makes. Humour does not only come from the incongruity of the compounds but can also be analysed in the light of superiority theory. Throughout the sitcom, the characters (often Barney) repeatedly mock Robin for being Canadian and they are frequently represented as not understanding cultural references and mocking these cultural elements, which they do not consider as serious. Among the occasionalisms which are not successfully understood, some endorse a further function at level 1: deception. 


\subsection{Pushing the limits of the purpose and success of occasionalisms? Deceptive occasionalisms}

The first example I will mention in this final section is "Dowisetrepla" (HIMYM 3x07). In this episode, Lily and Marshall want to buy an apartment; they visit one in a neighbourhood they have never heard of before and Lily has the following conversation with the real estate agent:

(45) REAL ESTATE AGENT: "Dowisetrepla. Oh, I see, you're not New Yorkers." LILY: "Oh, actually we live on the Upper West Side, so..." REAL ESTATE AGENT: "No need to be embarrassed, listen, here in New York we just shorten the names of all the neighborhoods, SoHo, TriBeCa, Nolita..." LILY: “Oh, right. Dowisetrepla. No, I'm, I'm from New York. I know this neighborhood." (HIMYM 3x07)

"Dowisetrepla" is obviously not understood by Lily and Marshall (even if Lily pretends that she does understand it) and only at the end of the episode do they and we understand what "Dowisetrepla" stands for, as shown in the following screenshot:

Figure 1. Lily and Marshall realise what "Dowisetrepla" stands for (HIMYM 3x07)

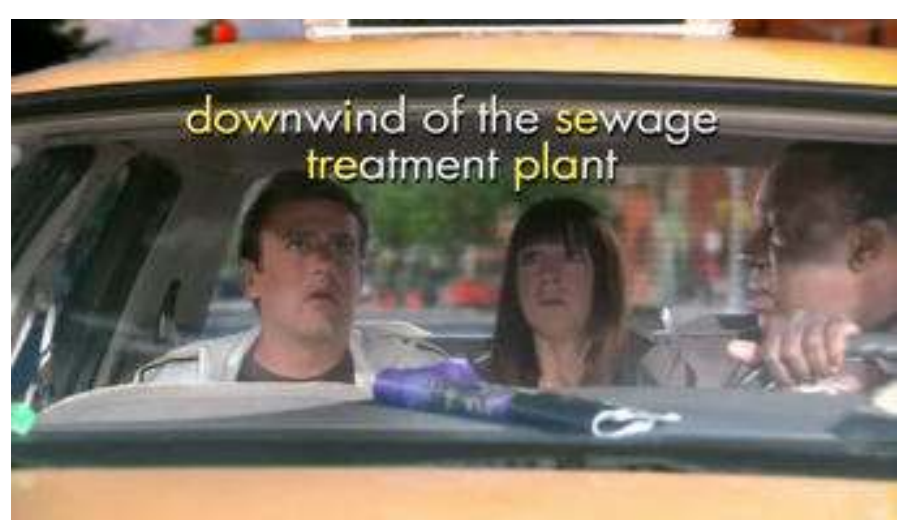

"Dowisetrepla" stands for "DOWnWInd of the SEwage TREatment PLAnt" and is a blend created via a five-time right shortening. The nonce formation process and the resulting occasionalism are complex, which explains why neither Lily nor the audience understand it when it is first mentioned, and which also accounts for the fact that it has to be written on screen to make sure that the audience fully understands. When Lily and Marshall finally grasp the meaning of "Dowisetrepla", they also realise that contrary to what they thought, its main purpose is not to designate the new neighbourhood with a trendy name, but rather to be deceptive. The real estate agent used this occasionalism to compensate for the fact that there is a terrible smell in the neighbourhood (as it is situated next to the sewage treatment plant, although Marshall and Lily did not smell it when they visited the apartment during the weekend) and to convince potential buyers. This is only made possible thanks to the opacity of the new name and to the fact that the process of right shortening is frequently used to name neighbourhoods in New York City. The occasionalism can be considered as extremely successful from the real estate agent's point of view as her main aim was to deceive potential buyers: Lily and Marshall made an offer on the apartment. From Lily and Marshall's point of view, the occasionalism was probably not successful until they understood its real purpose. From the audience's point of view, the occasionalism is 
successfully humorous as it is incongruous. Indeed, five-time right shortening is extremely rare and therefore leans towards creativity rather than productivity; Renner \& Renwick [2019], for example, only mention double right shortening. Humour also draws on the feeling of superiority that the audience feel when they understand that Marshall and Lily have been deceived by the real estate agent.

Although "Dowisetrepla" is not understood by the characters and is deceptive, it does have a meaning that is revealed at the end of the episode. Some occurrences, on the other hand, seem to question the very necessity for occasionalisms to have a meaning, as in HIMYM 4x14. In this episode, Robin is about to be deported to Canada because she is unemployed. Barney shows the other characters his video résumé (in which he uses occasionalisms) and offers to make one for Robin:

(46) BARNEY (in the video): "All my life, I have dared to go past what is possible."

BARNEY (interviewing himself in the video): "To the impossible?"

BARNEY (in the video): "Actually, past that... To the place where the possible

and the impossible meet to become... the possimpible."

TED: "The possimpible? Really?"

BARNEY: "Inventing your own word shows creativity and vision...

Visiativity." [...]

LILY: "That was ridiculous and insane."

MARSHALL: "Insanulous." (HIMIM 4x14)

"Possimpible" (quite a creative blend as it is a sandwich blend created via the addition of "imp-", which was itself created via right shortening, in the middle of "poss-ible") is defined by Barney as "the place where the possible and the impossible meet". This definition does not make much sense, and Barney later admits that the main purpose of this occasionalism is to show "creativity and vision", which is not a conventional purpose: Barney creates a signifier for which the signified is blurred. These occasionalisms are not really successful with Ted and Lily, but Marshall seems to appreciate the playfulness of the process and coins his own occasionalism ("insanulous"). At level 2, the incongruity of Barney's approach and the playful nature of blends give rise to humour. As Barney later explains, creating these "vague" words aims at "sounding" confident, which is a means to deceive potential employers:

(47) BARNEY: "So, what does being a reporter mean to you?"

ROBIN: "Well, ever since I was a little kid, I always..."

BARNEY: "Cut! You're getting bogged down in specifics. I need you to just say vague, confident-sounding buzzwords, like 'synergy' and 'dynamism'. You can make up a word, like... 'linkativity'."

ROBIN: "How will sounding like an idiot get me hired anywhere?"

BARNEY: “Okay, fine. Don't do it. Anyway, I'm sure there are plenty of exciting stories to cover back in Canada. I just read that the mayor of Winnipeg's nephew went ice fishing and caught himself a 16-pound walleye. Reporting live from the worst place in the world, I'm Robin Scherbatsky."

ROBIN: "Fine. Roll camera. Connectitude."

BARNEY: "Love it."

ROBIN: "Transformatation."

BARNEY: "Earn it!"

ROBIN: "Linkativity."

BARNEY: "Linkativity is mine." (HIMIM 4x14) 
Robin finally follows Barney's advice and creates her own blends via double inner shortening. The purpose of these occasionalisms is clearly called into question here: they are void of meaning and their main purpose at level 1 is to be deceptive. The aim is also for them to remain occasionalisms and not to become used by other characters ("Linkativity is mine"). Unexpectedly, they are nevertheless presented as successful as Barney argues the video résumé got him eleven job interviews and it got Robin a job: the deceptive purpose is successfully reached. At level 2, humour rises from the discrepancy between the theoretical basic purpose of creating an occasionalism (creating a signifier to designate a signified) and the purpose of these occasionalisms: the form becomes the message.

Occasionalisms are also purposely deceptive in HIMYM 6x08, as shown in examples (48) and (49):

(48) LILY: "Hey we're still those people. One of those days, Marshall is gonna quit his job, go work for the N.R.D.C. and save the world. Right baby?"

MARSHALL: "Absotively. Well, let's just remember, nobody's the same as they were in college." (HIMYM 6x08)

(49) LILY: "So, you've known about this for two and a half years? So, every time you've talked about wanting to be an environmental lawyer since then that was a lie?"

MARSHALL: "Technically, I never lied. You asked me questions and I responded with made-up words."

LILY: "What?"

Flashback

LILY: "So, you'll probably quit GNB in a couple of years, right?"

MARSHALL: "Affirmatootly."

LILY: "And become an environmental lawyer?"

MARSHALL: "Yepskerdoodles."

LILY: "Hey by the way, do you like this scarf?"

MARSHALL: "Posititochetochmecochapopocha."

Back to present day

MARSHALL: "Lawyered."

LILY: "Ok that's also a made-up word!" (HIMYM 6x08)

In this episode, Marshall successively uses four different occasionalisms which are increasingly complex and absurd. "Absotively" is created via a simple double inner shortening ("absolutely" + "positively"), and so is "affirmatootly" (although it is spelled with <0o> in the subtitles, it seems to be a blend of "affirmatively" and "absolutely"). "Yepskerdoodles", on the other hand, is much more creative and the nonce formation process is not really clear: it is clearly composed of "yep", but the rest is harder to identify. Similarly, "Posititochetochmecochapopocha" starts with "positi-", created via left-hand-side inner shortening, but the second part of the occasionalism does not seem to follow any known nonce formation process. In that respect, these last two occurrences are in between nonce formation and word creation and are particularly creative. Nevertheless, neither the occasionalisms which follow the rules of productivity (the first two) nor those which follow the rules of creativity (the last two) are meant to contain meaning: as Marshall explains, their purpose was to deceive Lily into thinking that he would quit his job at GNB. They can be considered as successful as Lily was indeed deceived. Words do not need to be creative to be deceitful; words following the rules of productivity can be deceitful as well. There is a sort of incongruity because Lily (and the audience) infer a meaning from these four 
occasionalisms: she bases her interpretation on the fact that she recognizes that the occasionalisms were partly created from words she does know. She is however deceived because Marshall argues that an occasionalism cannot fulfil their communicative function because they are "made-up". Incongruity also comes from the extraordinary length of these unknown words, which participates in the creation of humour together with Marshall's mimicking. These occasionalisms are particularly salient, creative occasionalisms, both in their form and in their function; the two combine to fulfil a humorous function at level 2, actively participating in HIMYM's overall approach to humour.

\section{Conclusion}

I hope I have successfully shown that in HIMYM, occasionalisms have both creative forms and creative purposes. These forms and purposes vary but all seem to participate in the overarching function of humour, which is the main aim of the sitcom at level 2. Some occasionalisms are represented as being partly unsuccessful or deceitful at level 1, but no occasionalism is entirely unsuccessful as they are not coined on the spur of the moment but carefully prepared by scriptwriters. Naturally, whether humour is successful or not does not solely depend on occasionalisms; I have shown that a variety of other factors need to be taken into account. Viewer's perception is also a major factor: the same occasionalism may not be as funny for one viewer as it will be for another, but this is quite difficult to measure.

Finally, I would argue that some occasionalisms are successful because they seem to have originated from the sitcom and are now used by viewers (this is the case of "GCWOK" (HIMYM 3x19)); others might not have been coined in the sitcom but have become popular thanks to the series sitcom or have become closely associated with the show (this is the case of "lawyered"). This is due to the special status of occasionalisms in sitcoms and in fiction in general: although they are technically only used once, they are actually heard by millions of viewers and the episodes are broadcast several times and on different platforms, which means that such occasionalisms spread faster than they would otherwise.

\section{BIBLIOGRAPHY}

\section{Corpus}

How I Met Your Mother: The Complete Series, 2005-2014. Created by Craig Thomas \& Carter Bays, CBS, DVD.

\section{Scripts}

Subslikescript, Subtitles like scripts, available at https://subslikescript.com/series/

How_I_Met_Your_Mother-460649 
Forever Dreaming, 2000-2021, “Transcripts”, available at https://transcripts.foreverdreaming.org/ viewforum.php?f=177

\section{Software}

ANTHONY Lawrence, 2020, AntConc (Version 3.5.9) [Computer Software], Tokyo, Japan: Waseda University.

\section{Dictionaries}

Merriam-Webster Dictionary online, https://www.merriam-webster.com (last accessed 08/12/2020).

Urban dictionary online, https://www.urbandictionary.com (last accessed 08/12/2020).

\section{References}

ADAMS Michael, 2003, Slayer Slang: a Buffy the Vampire Slayer Lexicon, New York: Oxford University Press.

BAUER Laurie, 1983, English Word-formation, Cambridge: Cambridge University Press.

BAUER Laurie, 2003, Introducing Linguistic Morphology (2 ${ }^{\text {nd }}$ ed.), Edinburgh: Edinburgh University Press.

BAUER Laurie, 2009, “Typology of Compounds”, in LIEBER Rochelle \& STEKAUER Pavol, The Oxford Handbook of Compounding, Oxford: Oxford University Press, 343-355.

BEERS FÄGERSTEN Kristy (Ed.), 2016, Watching TV with a Linguist, Syracuse, NY: Syracuse University Press.

BELIAEVA Natalia, 2019, "Blending Creativity and Productivity: on the Issue of Delimiting the Boundaries of Blends as a Type of Word Formation", Lexis 14: http://journals.openedition.org/ lexis/4004 (last accessed 23 November 2020).

BELL Nancy, 2015, We Are Not Amused: Failed Humor in Interaction, Berlin: Mouton de Gruyter.

CHANPIRA Erik Iossifovič, 1966, “Ob okkazionaL'nom slove i okkazionaL'nom slovoobrazovaniji”, Razvitije slovoobrazovanija sovremennogo russkogo jazyka, Moscow: Nauka, 153-166.

CORNILLON Claire, 2006, " How I Met your Mother, ou la fonction du récit », Télévisions 2006/1 n : 163-172.

CRYSTAL David, 2000, "Investigating Nonceness: Lexical Innovation and Lexicographic Coverage", Manuscript, Narrative and Lexicon: Essays on Literary and Cultural Transmission in Honor of Whitney F Bolton, Lewisburg: Bucknell University Press/London: Associated University Presses, 218-231.

DRESSLER Wolfgang U. \& TUMFART Barbara, 2017, "New Corpus-Linguistic Approaches to the Investigation of Poetic Occasionalisms: The case of Johann Nepomuk Nestroy", Yearbook of the Poznan Linguistic Meeting 3(1), De Gruyter Open, 155-166, also available at https:// www.degruyter.com/downloadpdf/j/yplm.2017.3.issue-1/yplm-2017-0008/ yplm-2017-0008.pdf://website.com DYNEL Marta, 2012a, "Humour on the House: Interactional Construction of Metaphor in Film Discourse", in CHOVANEC J. \& ERMIDA I. (Eds.), Language and Humour in the Media, Newcastle: Cambridge Scholars Publishing, 83-106.

DYNEL Marta, 2012b, "Setting our House in Order: the Workings of Impoliteness in Multi-party Film Discourse”, Journal of Politeness Research 8, (2), 161-194. 
DYNEL Marta, 2013, “A View on Humour Theory”, in DYNEL Marta, Developments in Linguistics Humour Theory, Amsterdam and Philadelphia: John Benjamins Publishing Company, 7-14. HASPELMATH Martin, 2002, Understanding Morphology, London: Arnold.

HOHENHAUS Peter, 2007, "How to Do Even More Things with Nonce Words (Other than Naming)", in MUNAT Judith (Ed.), Lexical Creativity, Texts and Contexts, Amsterdam \& Philadelphia: John Benjamins Publishing Company, 15-38.

HUMBLEY John, 2006, « La néologie : interface entre ancien et nouveau », in GREENSTEIN Rosalind, Publications de la Sorbonne, Vol. 28, Série 'Langues et langages', 91-104.

JAMET Denis \& TERRY Adeline, 2018, “Introduction”, Lexis 12: http://journals.openedition.org/ lexis/2521 (last accessed 23 November 2020).

LIEBER Rochelle \& STEKAUER Pavol, 2009, The Oxford Handbook of Compounding, Oxford: Oxford University Press.

LIPKA Leonhard, 1975, “Re-discovery Procedures and the Lexicon”, Lingua 37, 197-224.

LIPKA Leonhard, 2007, "Lexical Creativity, Textuality and Problems of Metalanguage", in MUNAT Judith (Ed.), Lexical Creativity, Texts and Contexts, Amsterdam \& Philadelphia: John Benjamins Publishing Company, 3-12.

MITTELL Jason, 2015, Complex TV: The Poetics of Contemporary Television Storytelling, New York \& London: New York University Press.

MUNAT Judith (Ed.), 2007, Lexical Creativity, Texts and Contexts, Amsterdam \& Philadelphia: John Benjamins Publishing Company, 15-38.

MUNAT Judith, 2015, “Lexical Creativity”, in JONES Rodney H., 2015, The Routledge Handbook of Language and Creativity, London \& New York: Routledge, 92-106.

PoIx Cécile, 2018, “Neology in Children's Literature: A Typology of Occasionalisms”, Lexis 12: http://journals.openedition.org/lexis/2111 (last accessed on 23 November 2020).

QUAGLIO Paul, 2009, Television Dialogue: The Sitcom Friends vs. Natural Conversation, Vol. 36, Amsterdam: John Benjamins Publishing Company.

RENNER Vincent, 2015, “Lexical Blending as Wordplay", in ZIRKER Angelika \& WINTER-FROEMEL Esme (Eds), Wordplay and Metalinguistic/Metadiscursive Reflection: Authors, Contexts, Techniques, and MetaReflection, Berlin: De Gruyter, 119-133.

RENNER Vincent \& RENWICK Adam, 2019, "New Lexical Blends in The Simpsons: a Formal Analysis of English Nonce Formations and their French Translations", Lexis 14: http://

journals.openedition.org/lexis/3829 (last accessed 23 November 2020).

RUIZ-GURILLO Leonor, 2016, Metapragmatics of Humor: Current Research Trends, Amsterdam \& Philadelphia: John Benjamins.

SABLAYROLLES Jean-François, 1997, « Néologismes : une typologie des typologies », Cahiers du CIEL 1996-1997, Université de Limoges, 11-48.

SABLAYROLLES Jean-François, 2015 « Néologismes ludiques : études morphologique et énonciativopragmatique ", in WINTER-FROEMEL Esme \& ZIKER Angelica, Enjeux du jeu de mots : perspectives linguistiques et littéraires, Berlin: De Gruyter, Series: The Dynamics of Wordplay, 2, 189-216 : https://www.degruyter.com/view/book/9783110408348/10.1515/9783110408348-009.xml 
SAMS Jessie, 2016, “Word-formation in HIMYM", in BEERS FÄGERSTEN Kristy (Ed.), Watching TV with a Linguist, Syracuse, NY: Syracuse University Press, 161-180.

SCHMID Hans-Jörg, 2008, "New Words in the Mind: Concept-Formation and Entrenchment of Neologisms”, Anglia, Vol. 126, Issue 1: https://www.degruyter.com/view/journals/angl/126/1/ article-p1.xml (last accessed 4 December 2008).

SCHMID Hans-Jörg, 2016 (2003), English Morphology and Word-Formation, Berlin: Erich Schmidt Verlag.

TERRY Adeline, 2019, L'expression métaphorique des tabous : entre euphémisme et dysphémisme. Étude linguistique d'un corpus de séries télévisées américaines, unpublished $\mathrm{PhD}$ dissertation, defended 24 June 2019 under the supervision of Prof. Denis JAMET, University of Lyon (Jean Moulin Lyon 3): http://www.theses.fr/2019LYSE3024

TOURNIER Jean, 2004 (1988), Précis de lexicologie anglaise, Paris: Ellipses.

\section{NOTES}

1. These will be extensively dealt with later on in the article.

2. This is widely accepted today, although productivity and creativity were first opposed.

3. Word-formation in TV series was also the focus of Adams [2003], who conducted a study on Buffy the Vampire Slayer and laid emphasis on the fact that it contributed to creating a linguistic identity in the series.

4. Nevertheless, as Quaglio [2009:27] argues about Friends, "the addition of humor may negatively impact the naturalness of the dialogues".

5. I would like to thank one of the anonymous reviewers for the helpful remarks that they made and that were added to this paragraph.

6. Available at: https://raw.githubusercontent.com/dwyl/english-words/master/words.txt.

7. Available at: https://github.com/janester/mad_libs/blob/master/ List\%20of\%20Proper\%20Nouns.txt.

8. All new words were at some point considered as nonce words as there was a time when they had only been used once; it therefore does not seem to be an issue to assume that nonce formation processes are similar to word formation processes.

9. See Jamet \& Terry [2018] for a discussion of the difference between semantic and lexical neology. Also see Terry [2019] for metaphors and metonymies in How I Met your Mother.

10. Metonymy is generally defined as working by contiguity of two concepts. In example (4), "go home with someone" is created via metonymy as it stands for "having sex with someone". It euphemistically designates the entire process of seducing someone, taking them home and having sexual intercourse.

11. The main character of the show is Ted Mosby. On their first date, he told Robin he loved her, a move that became known as "the Mosby". This can also be considered as a case of eponymy.

12. The word erection directly comes from Latin; the word rection exists in English but erection is not a prefixed form of rection.

13. The first noun in the compound is created via vertical conversion (see Tournier [2004: 112]).

14. https://www.urbandictionary.com/define.php?term=GCWOK

15. Occurrence (7) (BARNEY: "I'm getting a de-rection" (HIMYM 6x01)) could also look like a muddled up lexeme meant to produce a humorous effect; nevertheless, I do not think that "derection" is meant to resemble "direction". This is made quite clear when Barney pronounces in /'di: 'rekJen/.

16. Episodic compounds could also be considered as nonce compounds. 
17. Haplologic blends are created through segment overlap, in that case, the two-phoneme syllable /peI/.

18. Note that "lawyered" was probably not created in the sitcom.

19. In French, pulsion ludique.

20. My translation of the French text: « Il existe ainsi des mots - que l'on peut considérer comme inutiles - que l'on crée pour s'amuser [...]. Le langage humain est aussi un terrain de jeu et l'homme éprouve le besoin de jouer sur ce terrain comme sur d'autres : le troisième ressort de la création lexicale est la pulsion ludique. [...] ces ressorts peuvent se combiner, à deux, à trois, pour créer une nouveauté lexicale ».

21. Word-formation processes can also be resorted to for X-phemistic purposes (see Terry [2019]).

22. "Backronymy is a playful process in which the operation of initialization leads to an already existing word [...] Playfulness is increased when the meaning of the earlier word is associated with that of the new backronym." (Renner [2015: 120]).

23. This will not be further developed for lack of space, but see Dynel [2012b] for more details on participants in TV interactions.

24. This criterion cannot be used to identify humour in any sitcom. Canned laughter is culturally specific and is neither used in all countries nor in all American TV series.

25. BARNEY: "You're a sophisticated, scot-swilling, cigar-smoking, red-meat-eating, gun-toting New Yorker. What you are not is a massage-giving, windsurfing, bongo-playing, teetotaling, vegan, peacenik, hippy like your soon-to-be ex-boyfriend Gael." (HIMYM 3x02)

26. This occurrence is humorous because it is incongruous, but there is also a part of relief as the topic is sex.

27. I would like to thank one of the anonymous reviewers for the helpful remarks that they made and that were added to this paragraph.

28. In this episode, Marshall decides to offer the right to slap Barney to Ted or Robin.

29. This occurrence is close to haplologic blending even though voiced consonant $/ \mathrm{b} /$ is substituted for voiceless consonant $/ \mathrm{p} /$.

30. It could also be analysed as a case of compounding.

31. These occasionalisms also aim at functionalised hypostatisation, and this is reinforced by the fact that the showrunners created a website referencing those Canadian sex acts: https:// www.canadiansexacts.org.

\section{ABSTRACTS}

This paper focuses on the links between lexical creativity and humour in How I Met Your Mother, an American sitcom. More specifically, I analyse occasionalisms in order to determine how the word-formation processes used to create occasionalisms and the intended functions of those occasionalisms help create humorous potential for the viewers. Indeed, in the corpus, occasionalisms have both creative forms and creative purposes, and these forms and purposes vary but all seem to participate in the overarching function of humour. The paper also focuses on some occasionalisms that have unconventional functions, mostly those that are represented as being partly unsuccessful or deceitful. I also show that various factors have to be taken into account to analyse the humorous potential of occasionalisms. 
Cet article se concentre sur les liens entre créativité lexicale et humour dans How I Met Your Mother, une sitcome américaine. J'y analyse quelques occasionnalismes afin de déterminer comment les matrices lexicogéniques utilisées pour créer ces occasionnalismes et les fonctions visées par ces occasionnalismes contribuent à la création de potentiel humoristique pour les téléspectateurs. En effet, dans les occurrences retenues, les occasionnalismes sont créatifs à la fois par leur forme et leur fonction; ces formes et fonctions varient mais semblent toutes participer de manière plus large à la création de l'humour. L'article se concentre également sur certains occasionnalismes qui ont des fonctions non conventionnelles, principalement ceux qui sont représentés comme n'ayant pas le succès escompté ou comme étant trompeurs. Je montre également que divers facteurs doivent être pris en compte pour analyser le potentiel humoristique des occasionnalismes.

\section{INDEX}

Keywords: How I Met Your Mother, humour, lexical creativity, nonce formation, occasionalisms, sitcom, word-formation processes

Mots-clés: créativité lexicale, How I Met Your Mother, humour, matrices lexicogéniques, nonce formation, occasionnalismes, sitcom

\section{AUTHOR}

\section{ADELINE TERRY}

University of Lyon (Jean Moulin Lyon 3) \& CEL « Centre d'Études Linguistiques - Corpus, Discours et Sociétés »

adeline.terry@univ-lyon3.fr 